\title{
Apparent availability of nitrogen in composted municipal refuse
}

\author{
E. Iglesias-Jimenez, C. E. Alvarez \\ Instituto de Productos Naturales y Agrobiología de Canarias, CSIC, Avda. Francisco Sánchez 3, \\ E-38206 La Laguna, Tenerife, Canary Islands, Spain
}

Received: 21 December 1992

\begin{abstract}
The use of composted municipal refuse on agricultural land requires prior knowledge of the interactions among compost, soil, and plants. Research into the availability of $\mathrm{N}$ in highly matured municipal refuse compost is particularly important considering the current concern about groundwater contamination by $\mathrm{NO}_{3}^{-}-\mathrm{N}$. A greenhouse pot bioassay was conducted to determine the percentage of short-term apparent bioavailable $\mathrm{N}$ of a highly matured refuse compost and its relative efficiency in supplying inorganic $\mathbf{N}$ to the soil-plant system in comparison with $\mathrm{NH}_{4} \mathrm{NO}_{3}$. Municipal refuse (after 165 days of composting) was applied at rates equivalent to 10 , 20,30,40, and $50 \mathrm{tha}^{-1}$ to a ferrallitic soil from Tenerife Island (Andeptic Paludult). $\mathrm{NH}_{4} \mathrm{NO}_{3}$ was applied at rates equivalent to the total $\mathrm{N}$ content of the compost treatments. Perennial ryegrass (Lolium perenne L.) was grown in 3-kg pots and the tops were harvested at regular intervals after seedling emergence. The compost increased dry matter yield, soil mineral $\mathrm{N}$, and plant $\mathrm{N}$ uptake proportional to the applied rate. These increases were significantly higher than the control at an application rate of $20 \mathrm{t} \mathrm{ha}^{-1}$. After 6 months the apparent bioavailable $\mathrm{N}$ ranged from 16 to $21 \%$. The relative efficiency was $43 \%$ after 30 days. This suggests that large inputs of inorganic $\mathrm{N}$ into soil can be obtained with high rates of this kind of compost, with a potential for $\mathrm{NO}_{3}^{-}-\mathrm{N}$ contamination. However, applied at moderate rates in our bioassay $\left(<50 \mathrm{t} \mathrm{ha}^{-1}\right)$, compost showed a low $\mathrm{N}$-supplying capacity to ryegrass, i.e. a small fraction of the mineralized compost $\mathrm{N}$ was used by plants in the course of time. This was ascribed to a partial biological immobilization. This pattern of $\mathrm{N}$ availability in highly matured municipal refuse compost, positive net mineralization but partial immobilization, is similar to the pattern of $\mathrm{N}$ availability in biologically active soils and is therefore extremely interesting for the conservation of $\mathrm{N}$ in agro-ecosystems.
\end{abstract}

Correspondence to: E. Iglesias-Jimenez
Key words: Compost - N mineralization - Organic $\mathrm{N}$ - Plant $\mathrm{N}$ uptake - Soil $\mathrm{N}$ availability - $\mathrm{N}$ immobilization

Land application of composted municipal refuse, produced by aerobic thermophilic digestion of the organic fraction of municipal solid wastes, is an attractive alternative for the disposal of these wastes, currently land-filled or incinerated. The recycling of organic wastes through composting can mitigate problems of both environmental pollution and soil degradation (Mathur et al. 1990). To determine the suitability of composted municipal refuse for agricultural use, it is necessary to evaluate its reaction with soils and the crop response (Sims 1990). Composted municipal refuse normally improves physical and chemical soil properties such as porosity, aggregate stability, water-holding capacity, pH-buffering capacity and cation-exchange capacity, and also releases nutrients gradually (Pagliai et al. 1981; Giusquiani et al. 1988; Piccolo and Mbagwu 1990; Iglesias-Jiménez et al. 1993). Similarly, this composted refuse has a positive influence on soil microorganisms and soil enzyme activities (Nishio and Kurano 1980; Miyashita et al. 1982; Perucci 1990). Moreover, the mature compost may reduce phytopathogenic fungi levels (Van Assche and Uyttebroeck 1981; Phae et al. 1990) and nematode plant-parasite populations (Rodriguez-Kabana et al. 1987). Nevertheless, negative effects, normally associated with a decrease in yield, have also been reported, and are caused by the application of large amounts of compost with high levels of available heavy metals (Petruzzelli 1989) and the use of immature compost, i.e., insufficiently stabilized as regards mineralization and "humification" (Iglesias-Jiménez and PérezGarcía 1989).

A wide range of results has been obtained in relation to the efficiency of compost as a source of $\mathrm{N}$ for plants because $\mathrm{N}$ availability is closely related to the degree of compost maturity (Gallardo-Lara and Nogales 1987). Immature composts induce a considerable increase in soil 
microbial activity to decompose the excess of labile $\mathrm{C}$ compounds, potentially causing a strong immobilization of native and added available $\mathrm{N}$, and consequently, $\mathrm{N}$ starvation and depressive effects on crop plants may occur (Iglesias-Jiménez and Pérez-García 1989; Sims 1990). In contrast, highly matured composts normally increase crop yields and a net inorganic- $\mathrm{N}$ accumulation may occur in the soil (King 1984). Thus, knowledge of the availability of $\mathrm{N}$ in composts is particularly important, given the current concern with groundwater contamination by $\mathrm{NO}_{3}^{-}-\mathrm{N}($ Sims 1990) and the scarcity of values reported for $\mathrm{N}$ mineralization from composted domestic refuse. The objective of the present study was to evaluate the $\mathrm{N}$ supplying capacity of a highly matured municipal refuse compost by means of a ryegrass pot bioassay, based on (1) the apparent availability of compost $\mathrm{N}$ over a period of 6 months and (2) the relative efficiency of compost as an $\mathrm{N}$ source compared to $\mathrm{NH}_{4} \mathrm{NO}_{3}$.

\section{Materials and methods}

\section{Properties of composted municipal refuse}

The composted municipal refuse used in this study was obtained in a controlled pile-composting trial from the organic fraction of the municipal solid waste of Santa Cruz de Tenerife (Canary Islands), after a biooxidative period of 75 days and a 90-day complementary maturity process. The composting system and the evolution of maturity during composting have been presented previously (Iglesias-Jiménez and PérezGarcía 1991, 1992 a). Some chemical characteristics of the final product (165 days of composting) are shown in Table 1. This compost had an exceptionally high degree of maturity; in an earlier study (IglesiasJiménez and Pérez-García 1992b) a $C: N$ ratio $<12$ was estimated to ensure a high degree of maturity, in combination with other parameters of maturity such as a cation-exchange capacity of $>67 \mathrm{cmol}(+) \mathrm{kg}^{-1}$

Table 1. Main characteristics of composted municipal refuse

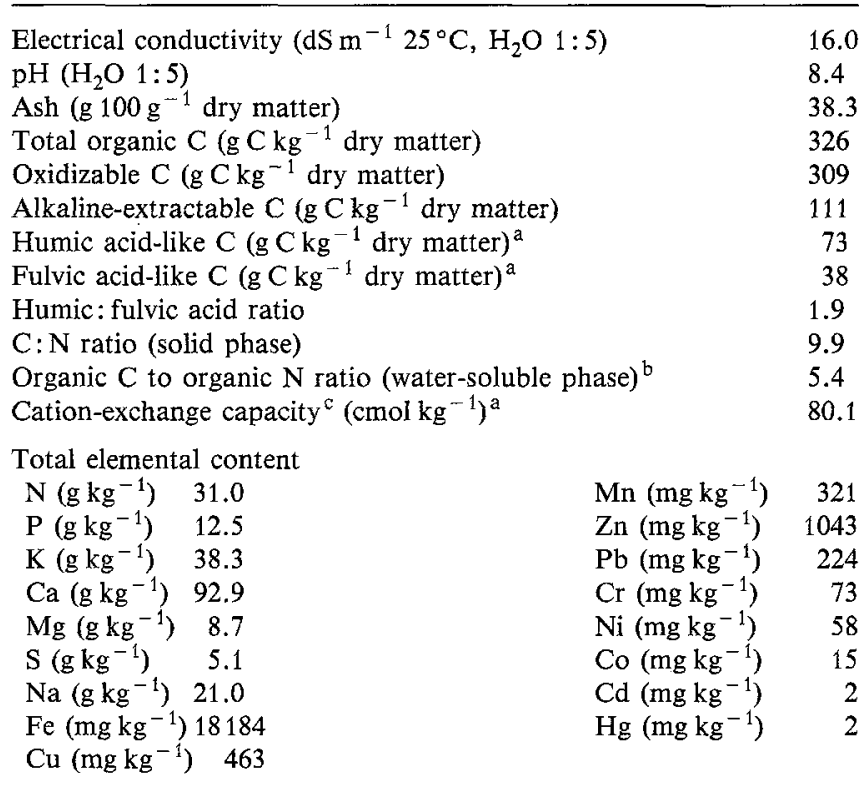

${ }^{a}$ Ash-free material basis

${ }^{b}$ Chanyasak and Kubota (1981) procedure

${ }^{c}$ Harada and Inoko (1980) procedure dry matter on an ash-free material basis, $C: N$ (compost:water $1: 5)<6$, and a humic acid to fulvic acid ratio of $>1.6$. Moreover, the final compost had an intense black colour and a strong odour similar to that of "damp forest ground", normally attributed to the excretion of geosmine, a secondary metabolite produced by mesophilic actinomycetes, which predominate during the maturation phase of composting (De Bertoldi and Zucconi 1980). Before incorporation with the soil, the compost subsample for this experiment $(8 \mathrm{~kg})$ was air-dried, ground to pass a 1-mm sieve, and throughly homogenized. The total elemental content shown in Table 1 is from this subsample (average of five repetitions). The $\mathrm{pH}\left(\mathrm{H}_{2} \mathrm{O}, 1: 5\right)$ of this subsample was 6.8 and the $\mathrm{C}: \mathrm{N}$ ratio 11.3 .

\section{Greenhouse study}

The experiment was conducted over 7 months under a controlled greenhouse environment (temperature $16-24^{\circ} \mathrm{C}$, relative humidity $60-85 \%$ ), in plastic pots containing $3 \mathrm{~kg}$ air-dried soil. The soil was a variable-charge soil from Tenerife, Canary Islands (Andeptic Paleudult), comprising $26 \%$ sand, $34 \%$ silt, and $40 \%$ clay, with $\mathrm{pH}$ $\left(\mathrm{H}_{2} \mathrm{O}\right) 5.8$, electrical conductivity $1.00 \mathrm{dS} \mathrm{m}^{-1}$, organic $\mathrm{C} 16.5 \mathrm{~g} \mathrm{~kg}^{-1}$, cation-exchange capacity $21.2 \mathrm{cmol}(+) \mathrm{kg}^{-1}, \mathrm{C}: \mathrm{N}$ ratio 11.6 , $\mathrm{NH}_{4}^{+}+\mathrm{NO}_{3}^{-} 53 \mathrm{mg} \mathrm{N} \mathrm{kg}^{-1}$, labile $\mathrm{P}$ (Olsen) $20 \mathrm{mg} \mathrm{P} \mathrm{kg}^{-1}$, and $\mathrm{NH}_{4} \mathrm{OAc}$-extractable $\mathrm{K} 321 \mathrm{mg} \mathrm{K} \mathrm{kg}{ }^{-1}$. Halloysite was the dominant clay mineral and small amounts of gibbsite and allophane were also present.

The soil sample was passed through a 4-mm screen to remove rocks, roots, and other large particles. Complete randomized blocks were chosen as the experimental design (Little and Hills 1975). Five compost treatments equivalent to $10,20,30,40$, and $50 \mathrm{t} \mathrm{ha}^{-1}$ were established as well as five treatments with $\mathrm{NH}_{4} \mathrm{NO}_{3}$ on the basis of the $\mathrm{N}$ content of the compost treatments. The $\mathrm{NH}_{4} \mathrm{NO}_{3}$ treatments were also supplied with $\mathrm{P}, \mathrm{K}, \mathrm{Ca}, \mathrm{Mg}, \mathrm{S}, \mathrm{Na}, \mathrm{Cu}, \mathrm{Fe}, \mathrm{Mn}$, and $\mathrm{Zn}$ at rates equivalent to that supplied in the compost treatments. A control (no treatment) was also established. Perennial ryegrass (Lolium perenne $\mathrm{L}$.) was used as the test plant. In each pot 1000 seeds were planted and $400 \mathrm{ml}$ deionized water was added immediately after planting to germinate the seeds. Germination was completed in 7 days. The pots were watered daily with deionized water to bring the soil moisture to a level corresponding to $33 \mathrm{kPa}$ tension (25\% moisture). All pots were harvested $30,60,90,120,150$, and 180 days after seedling emergence by cutting the plant tops $2 \mathrm{~cm}$ above the soil surface. The total number of pots used was 253,55 of which were used for plant nutrient assays (11 treatments $\times 5$ replications) and 198 to study nutrient changes in the soil (11 treatments $\times 3$ replications $\times 6$ harvesting periods).

The ryegrass tops were dried at $80^{\circ} \mathrm{C}$ in a forced-draught cabinet oven to a constant weigth. The dried plant material was ground to powder in a stainless steel mill and, just before the analytical process, the ground samples were dried again at $105^{\circ} \mathrm{C}$ for $2 \mathrm{~h}$. Plant $\mathrm{N}$ was determined titrimetrically following a semimicro-Kjeldahl digestion method (Bremner 1965a). Soil samples were air-dried, ground, sieved ( $2 \mathrm{~mm}$ ) and stored at $4^{\circ} \mathrm{C}$. Subsamples $(10 \mathrm{~g})$ were extracted with $2 \mathrm{~N} \mathrm{KCl}$ $(1: 10, w: v)$ and inorganic $\mathrm{N}\left(\mathrm{NH}_{4}^{+}+\mathrm{NO}_{3}^{-}\right)$was determined titrimetrically following steam distillation with $\mathrm{MgO}$ and Devarda's alloy (Bremner 1965b).

\section{Statistical analyses}

Plant and soil analysis data were subjected to analysis of variance. Whenever the analysis of variance $F$ value was significant, Duncan's new multiple range test was used to determine difference among treatments at $P=0.01$ (Little and Hills 1975). To calculate regression equations and correlation coefficients relating plant growth, plant $\mathrm{N}$ uptake and soil mineral N, the Statistical Graphics System Program (STSC, Lauer Software) was used.

The percentage of apparent bioavailable nitrogen $(\mathrm{ABN} \%)$ was calculated according to the expression $\mathrm{ABN} \%=100\left(\mathrm{~N}_{\mathrm{f}}+\mathrm{Ni}_{\mathrm{f}}\right) / \mathrm{F}$, where $\mathrm{N}_{\mathfrak{f}}$ is the $\mathrm{N}$ taken up by ryegrass tops from the applied fertilizer, calculated as $N_{f}=N_{t}-N_{s}\left[N_{t}\right.$, total plant $N$ uptake; $N_{s}, N$ derived from the soil $\mathrm{N}$ reserve, assumed to be equivalent to the $\mathrm{N}$ uptake by the control (Greenwood et al. 1987)]; $\mathrm{Ni}_{\mathrm{f}}$ is the soil inorganic $\mathrm{N}$ derived from the 
applied fertilizer, calculated as $\mathrm{Ni}_{\mathrm{f}}=\mathrm{Ni}_{\mathrm{t}}-\mathrm{Ni}_{\mathrm{s}}\left(\mathrm{Ni}_{\mathrm{t}}\right.$, total inorganic $\mathrm{N}$; $\mathrm{Ni}_{\mathrm{s}}$, inorganic $\mathrm{N}$ derived from the soil $\mathrm{N}$ reserve); and $\mathrm{F}$ is the total $\mathrm{N}$ applied in the fertilizer.

The sum $\mathrm{N}_{\mathrm{f}}+\mathrm{Ni}_{\mathrm{f}}$ is considered the net ("apparent") mineralized $\mathrm{N}$, since the possible losses of $\mathrm{N}$ by denitrification or volatilization, and $\mathrm{N}$ in the roots are not taken into account. However, it was assumed that no leaching losses of $\mathrm{NO}_{3}^{-}-\mathrm{N}$ occurred under our experimental conditions. From $\mathrm{N}_{\mathrm{f}}$ the percentage of $\mathrm{N}$-fertilizer use by the plant (NFU\%) was calculated as NFU\% $=100\left(\mathrm{~N}_{\mathrm{f}} / \mathrm{F}\right)$, and the percentage of $\mathrm{N}$ in the plant derived from the applied fertilizer (NPF\%) was calculated as $\mathrm{NPF} \%=100\left(\mathrm{~N}_{\mathrm{f}} / \mathrm{N}_{\mathrm{t}}\right)$.

To compare the relative efficiency (RE) of the compost with that of $\mathrm{NH}_{4} \mathrm{NO}_{3}$ the following expression was used:

$$
\mathrm{RE} \%=\frac{\beta_{\text {compost }}}{\beta \mathrm{NH}_{4} \mathrm{NO}_{3}} \times 100
$$

where $\beta$ compost and $\beta \mathrm{NH}_{4} \mathrm{NO}_{3}$ represent the slopes of the linear (or semilog) functions used to describe the relationship between the total amount of $\mathrm{N}$ applied by the $\mathrm{N}$ source $(\mathrm{F})$ as an independent variable, and $\mathrm{N}_{\mathrm{f}}$ (or $\mathrm{N}_{\mathrm{f}}+\mathrm{Ni}_{\mathrm{f}}$ ) as a dependent variable.

\section{Results and discussion}

The response in plant growth $(Y)$ to the compost-N rate $(X)$ after 6 months was linear in form: $Y\left(\mathrm{~g} \mathrm{pot}^{-1}\right)=$ $8.3+3.7 X\left(\mathrm{~g} \mathrm{~N} \mathrm{pot}^{-1}\right), r^{2}=0.993$. The response to $\mathrm{NH}_{4} \mathrm{NO}_{3}$ fertilizer was greater, but the regression equation had a significant quadratic component: $Y=7.4+$ $27.9 X-4.4 X^{2}, r^{2}=0.992$. The plant $\mathrm{N}$ uptake with both treatments followed a similar pattern, which was linear for the compost treatments: $Y$ (mg N pot $\left.{ }^{-1}\right)=$ $156.6+104 X\left(\mathrm{~g} \mathrm{~N} \mathrm{pot}^{-1}\right), r^{2}=0.988$, and polynomial for the $\mathrm{NH}_{4} \mathrm{NO}_{3}$ treatments: $Y=117.9+926.8 X-97.2$ $X^{2}, r^{2}=0.991$. The response in cumulative yield and cumulative $\mathrm{N}$ uptake was consistently proportional to the compost rate (Fig. 1), and significantly higher than that of the control at rates of $20 \mathrm{tha}^{-1}$ and upwards. A slight increase in the slope of the regression lines was also observed, both for cumulative yield and cumulative $\mathrm{N}$ uptake versus time. After 6 months the compost-induced increase in yield in relation to the control was $30 \%(10 \mathrm{t}$ $\left.\mathrm{ha}^{-1}\right), 43 \%\left(20 \mathrm{t} \mathrm{ha}{ }^{-1}\right), 72 \%\left(30 \mathrm{tha}^{-1}\right), 94 \% \quad(40 \mathrm{t}$ $\left.\mathrm{ha}^{-1}\right)$, and $106 \%\left(50 \mathrm{t} \mathrm{ha}^{-1}\right)$. The increase in yield with the $\mathrm{NH}_{4} \mathrm{NO}_{3}$ treatments ranged from $136(10 \mathrm{t} \mathrm{ha}-1$ equivalent-rate) to $495 \%$ (50 t ha ${ }^{-1}$ equivalent-rate). These results showed the limited capacity of the compost to supply $\mathrm{N}$ to the plants in comparison with $\mathrm{NH}_{4} \mathrm{NO}_{3}$. However, the compost did not depress crop yields. The increase in cumulative yield and cumulative $\mathrm{N}$ uptake, proportional to the rate of compost application, occurs only with highly matured composts. Decomposition of organic materials with $\mathrm{C}: \mathrm{N}$ ratios $>25$ is known to result in net immobilization of native or added inorganic N (Sims 1990). Moreover, immature composts introduce phytotoxic compounds into the soil $\left(\mathrm{NH}_{3}\right.$, ethylene oxide, low-molecular-weight fatty acids), and also decrease the $\mathrm{O}_{2}$ concentration and the redox potential (IglesiasJiménez and Pérez-García 1989; Mathur et al. 1990). As a result, a reducing environment may be created in the rhizosphere which may lead to a decrease in root respiration and nutrient absorption, depressing plant growth compared with unamended soils (Iglesias-Jiménez and Pérez-García 1989).
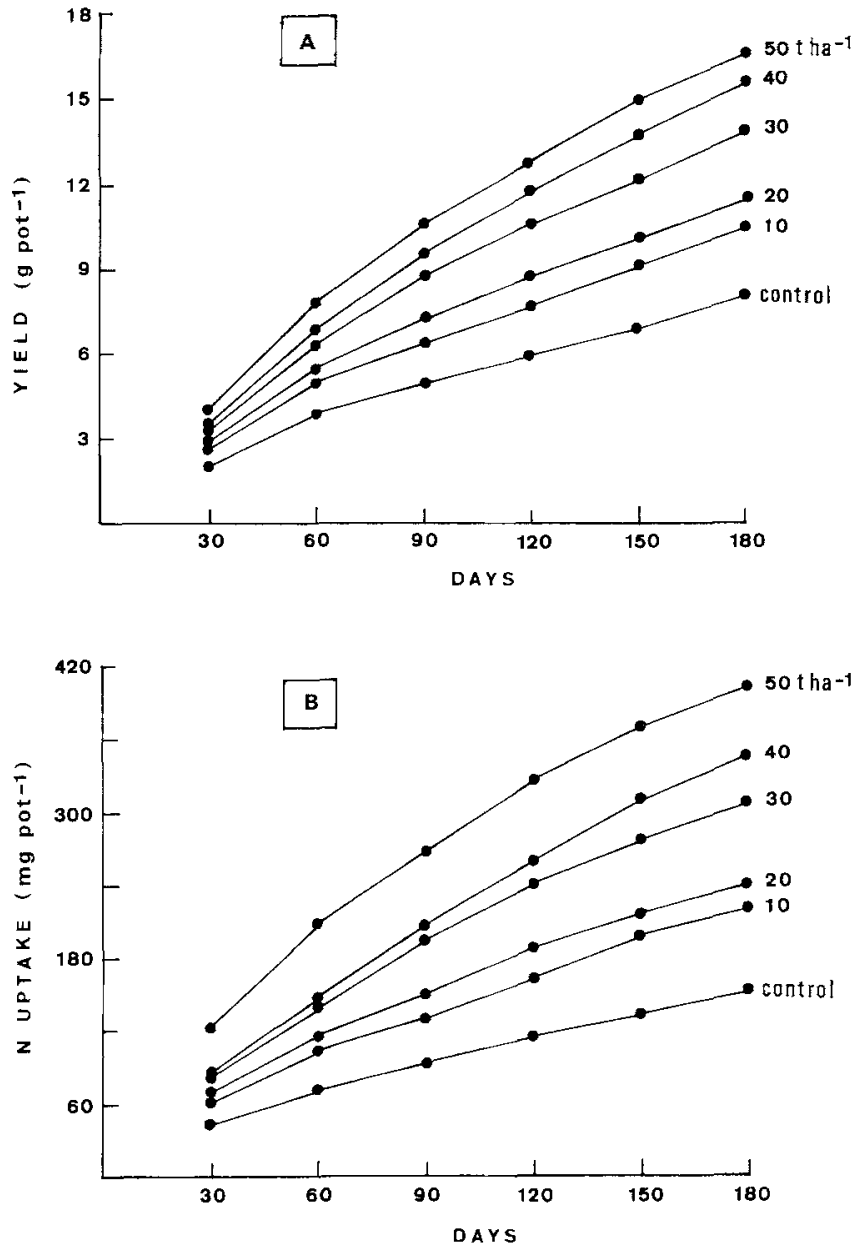

Fig. 1A, B. Cumulative yield (A) and cumulative $\mathrm{N}$ uptake (B) for five treatments with composted municipal refuse and the control

Plant $\mathrm{N}$ concentrations for all sources, rates, and harvesting periods are shown in Table 2. During the experiment there were generally small differences between the mean values of the compost treatments, but a slight increase in proportion to the applied rates was observed, especially during the first 3 months. The results of the 1st month are noteworthy since all the compost treatments significantly exceeded the control. However, plant $\mathrm{N}$ values were very low. Although critical values for plant $\mathrm{N}$ in herbage are not often cited, Bolton et al. (1976) and Goh and Kee (1978) reported critical deficient levels for Lolium perenne of $25 \mathrm{~g} \mathrm{~kg}^{-1}$ and $29 \mathrm{~g} \mathrm{~kg}^{-1}$, respectively; Benton Jones et al. (1991) reported a sufficiency range for optimum yields of between 45 and $50 \mathrm{~g} \mathrm{~kg}^{-1}$. Over the entire experimental period of the present study, the compost was a poor $\mathrm{N}$-supplying material to ryegrass, but it provides relatively large amounts of inorganic $\mathrm{N}$, particularly with compost rates of 40 and $50 \mathrm{tha}^{-1}$ (Table 3 ). The increase in soil available $\mathrm{N}$ was always significantly higher than in the control from rates of $20 \mathrm{tha}^{-1}$ and upwards, but it was especially noticeable that at $50 \mathrm{t}$ $\mathrm{ha}^{-1}$ the compost provided significantly larger amounts of available $\mathrm{N}$ than the $\mathrm{NH}_{4} \mathrm{NO}_{3}$ fertilizer at $20 \mathrm{tha}^{-1}$ equivalent-rate during the first 120 days and even, in some cases, equal to the $\mathrm{NH}_{4} \mathrm{NO}_{3}$ fertilizer at $30 \mathrm{tha}^{-1}$ 
Table 2. Changes in $\mathrm{N}$ concentrations $\left(\mathrm{g} \mathrm{kg}^{-1}\right)$ in ryegrass tops grown in soil treated with municipal refuse compost or with $\mathrm{NH}_{4} \mathrm{NO}_{3}$

\begin{tabular}{lcccccc}
\hline \multicolumn{7}{c}{ Days after seedling emergence } \\
\cline { 2 - 7 } & 30 & 60 & 90 & 120 & 150 & 180 \\
\hline Control & $19.9 \mathrm{~d}$ & $17.1 \mathrm{~d}$ & $19.1 \mathrm{e}$ & $23.4 \mathrm{~cd}$ & $19.4 \mathrm{fg}$ & $16.9 \mathrm{~d}$ \\
Compost treatment $\left(\mathrm{t} \mathrm{ha}^{-1}\right)$ & & & & \\
10 & $23.7 \mathrm{c}$ & $17.5 \mathrm{~d}$ & $19.0 \mathrm{e}$ & $25.0 \mathrm{c}$ & $25.5 \mathrm{bc}$ & $16.9 \mathrm{~d}$ \\
20 & $23.0 \mathrm{c}$ & $18.9 \mathrm{~d}$ & $19.8 \mathrm{e}$ & $24.7 \mathrm{c}$ & $21.0 \mathrm{efg}$ & $18.0 \mathrm{~cd}$ \\
30 & $24.4 \mathrm{c}$ & $19.1 \mathrm{~d}$ & $22.8 \mathrm{~d}$ & $25.8 \mathrm{c}$ & $22.9 \mathrm{cde}$ & $18.9 \mathrm{~cd}$ \\
40 & $24.7 \mathrm{c}$ & $18.6 \mathrm{~d}$ & $22.8 \mathrm{~d}$ & $24.7 \mathrm{c}$ & $24.3 \mathrm{bcd}$ & $19.4 \mathrm{~cd}$ \\
50 & $30.2 \mathrm{~b}$ & $23.1 \mathrm{c}$ & $21.3 \mathrm{~cd}$ & $26.5 \mathrm{c}$ & $21.0 \mathrm{efg}$ & $19.4 \mathrm{~cd}$ \\
$\mathrm{NH}_{4} \mathrm{NO}_{3}$ treatment $\left(\mathrm{t} \mathrm{ha} \mathrm{a}^{-1}\right.$ & compost) & & & \\
10 & $38.3 \mathrm{a}$ & $23.8 \mathrm{c}$ & $21.0 \mathrm{de}$ & $20.4 \mathrm{~d}$ & $18.6 \mathrm{~g}$ & $17.4 \mathrm{~cd}$ \\
20 & $39.6 \mathrm{a}$ & $34.2 \mathrm{~b}$ & $27.6 \mathrm{c}$ & $25.7 \mathrm{c}$ & $22.1 \mathrm{def}$ & $19.9 \mathrm{c}$ \\
30 & $38.5 \mathrm{a}$ & $34.3 \mathrm{~b}$ & $33.0 \mathrm{a}$ & $32.0 \mathrm{~b}$ & $26.5 \mathrm{~b}$ & $26.0 \mathrm{~b}$ \\
40 & $39.5 \mathrm{a}$ & $36.6 \mathrm{a}$ & $29.9 \mathrm{bc}$ & $38.3 \mathrm{a}$ & $31.6 \mathrm{a}$ & $28.2 \mathrm{~b}$ \\
50 & $40.8 \mathrm{a}$ & $37.4 \mathrm{a}$ & $30.9 \mathrm{ab}$ & $40.6 \mathrm{a}$ & $34.2 \mathrm{a}$ & $32.3 \mathrm{a}$ \\
\hline
\end{tabular}

Values within the same columns followed by the same letter are not significantly different at $P=0.01$ (Duncan's multiple range test)

equivalent-rate. The evolution with time in soil-available $\mathrm{N}$ was negative, but a positive net $\mathrm{N}$ accumulation (adjusted for native soil mineral $\mathrm{N}$ ) always took place, suggesting that only a fraction of the net mineralized compost $\mathrm{N}$ was used by the ryegrass during the experimental period. Figure 2 shows that the ryegrass plants observed more $\mathrm{N}$ from the fertilizer source than from the compost source for the same soil available- $\mathrm{N}$ level. A greater $\mathrm{NO}_{3}^{-}-\mathrm{N}: \mathrm{NH}_{4}^{+}-\mathrm{N}$ ratio in the $\mathrm{NH}_{4} \mathrm{NO}_{3}$-amended soil during the whole experimental period may account for this finding, assuming that the plants were able to absorb more $\mathrm{NO}_{3}^{-}$than $\mathrm{NH}_{4}^{+}$. Although Jarvis (1987) demonstrated that the rate of absorption for $\mathrm{NH}_{4}^{+}$in Lolium perenne growing in solution culture was greater than that for $\mathrm{NO}_{3}^{-}$with moderate supplies of $\mathrm{N}$, in general the effects of the different forms of $\mathrm{N}$ on growth were slight. Regression analyses between nutrient uptake and soil

Table 3. Variations in inorganic $\mathrm{N}\left(\mathrm{NO}_{3}-\mathrm{N}+\mathrm{NH}_{4}-\mathrm{N}, \mathrm{mg} \mathrm{N} \mathrm{kg}^{-1}\right)$ in soil amended with municipal refuse compost or $\mathrm{NH}_{4} \mathrm{NO}_{3}$

\begin{tabular}{lcccccc}
\hline \multicolumn{7}{c}{ Days after ryegrass seedling emergence } \\
\cline { 2 - 7 } & 30 & 60 & 90 & 120 & 150 & 180 \\
\hline Control & $60 \mathrm{~g}$ & $43 \mathrm{f}$ & $32 \mathrm{f}$ & $36 \mathrm{e}$ & $20 \mathrm{f}$ & $22 \mathrm{e}$ \\
Compost treatment & $\left(\mathrm{t} \mathrm{ha}^{-1}\right)$ & & & & \\
10 & $93 \mathrm{fg}$ & $51 \mathrm{f}$ & $61 \mathrm{e}$ & $74 \mathrm{~d}$ & $42 \mathrm{e}$ & $30 \mathrm{e}$ \\
20 & $101 \mathrm{f}$ & $74 \mathrm{e}$ & $63 \mathrm{de}$ & $86 \mathrm{~cd}$ & $71 \mathrm{~d}$ & $56 \mathrm{~d}$ \\
30 & $138 \mathrm{de}$ & $102 \mathrm{~d}$ & $71 \mathrm{de}$ & $102 \mathrm{c}$ & $65 \mathrm{~d}$ & $65 \mathrm{~d}$ \\
40 & $163 \mathrm{~d}$ & $112 \mathrm{~d}$ & $114 \mathrm{c}$ & $126 \mathrm{~b}$ & $79 \mathrm{~d}$ & $58 \mathrm{~d}$ \\
50 & $206 \mathrm{c}$ & $117 \mathrm{~d}$ & $113 \mathrm{c}$ & $129 \mathrm{~b}$ & $76 \mathrm{~d}$ & $61 \mathrm{~d}$ \\
$\mathrm{NH}_{4} \mathrm{NO}_{3}$ treatment $\left(\mathrm{t}\right.$ ha $\left.{ }^{-1} \mathrm{compost}\right)$ & & & \\
10 & $87 \mathrm{fg}$ & $38 \mathrm{f}$ & $25 \mathrm{f}$ & $22 \mathrm{e}$ & $16 \mathrm{f}$ & $24 \mathrm{e}$ \\
20 & $114 \mathrm{ef}$ & $86 \mathrm{e}$ & $83 \mathrm{~d}$ & $72 \mathrm{~d}$ & $67 \mathrm{~d}$ & $51 \mathrm{~d}$ \\
30 & $211 \mathrm{c}$ & $175 \mathrm{c}$ & $167 \mathrm{~b}$ & $126 \mathrm{~b}$ & $114 \mathrm{c}$ & $93 \mathrm{c}$ \\
40 & $279 \mathrm{~b}$ & $204 \mathrm{~b}$ & $169 \mathrm{~b}$ & $230 \mathrm{a}$ & $174 \mathrm{~b}$ & $123 \mathrm{~b}$ \\
50 & $334 \mathrm{a}$ & $270 \mathrm{a}$ & $204 \mathrm{a}$ & $215 \mathrm{a}$ & $224 \mathrm{a}$ & $144 \mathrm{a}$ \\
\hline
\end{tabular}

See footnote to Table 2

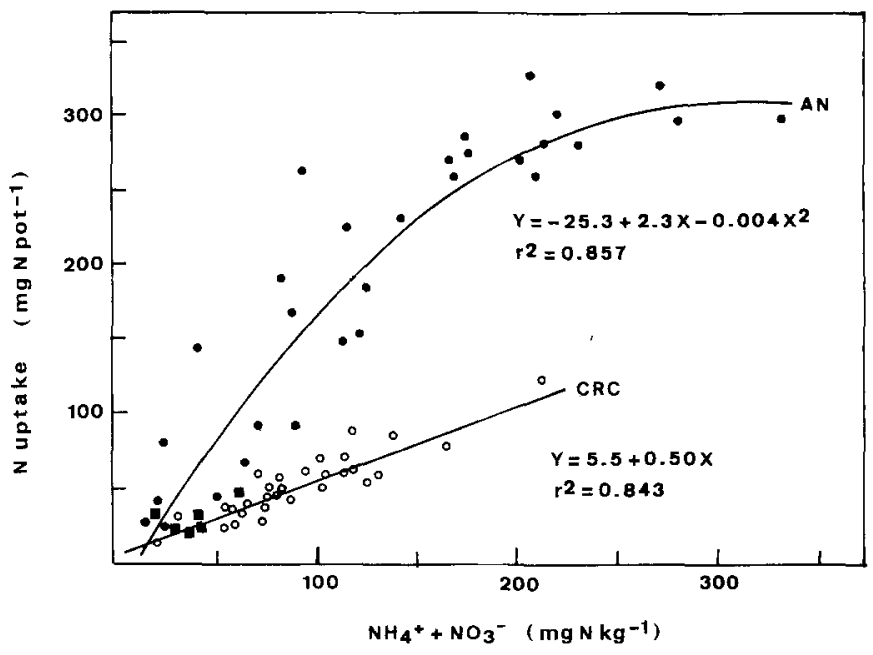

Fig. 2. Relationships between plant $\mathrm{N}$ uptake and soil inorganic $\mathrm{N}$ for city refuse compost $(C R C)$ and $\mathrm{NH}_{4} \mathrm{NO}_{3}$ treatments $(A N)$. The regression analysis was performed by taking into account all the data points (average values) from all treatments and harvesting periods $(n=36)$

available $\mathrm{P}, \mathrm{K}, \mathrm{Ca}$, and $\mathrm{Mg}$, and between dry-matter yields and plant nutrient concentrations showed that none of these nutrients was a yield-limiting factor. As discussed below, significant $\mathrm{NH}_{3}$ volatilization in compostamended soil was not expected under our experimental conditions. Thus, differences in the rate of plant uptake of soil mineral $\mathrm{N}$ may be ascribed to competition between plants and soil microorganisms for this nutrient, suggesting that partial biological immobilization may have taken place. This may also have occurred in the $\mathrm{NH}_{4} \mathrm{NO}_{3}$ amended soil, but the extent of $\mathrm{N}$ immobilization seems to be greater in compost treatments due to stimulation of soil microbial biomass and enzyme activities, a wellknown effect of mature composts (Miyashita et al. 1982; Marchesini et al. 1988; Perucci 1990).

The percentages of $\mathrm{N}$-fertilizer use by the plant, plant $\mathrm{N}$ derived from fertilizer, and apparent bioavailable $\mathrm{N}$ are given in Table 4 for the five compost and $\mathrm{NH}_{4} \mathrm{NO}_{3}$ treat-

Table 4. Percentage of $\mathrm{N}$-fertilizer use (NFU\%), plant $\mathrm{N}$ derived from fertilizer (NPF\%), and apparent bioavailable $\mathrm{N}(\mathrm{ABN} \%)$ in treatments with city refuse compost (CRC) and $\mathrm{NH}_{4} \mathrm{NO}_{3}$ (AN)

\begin{tabular}{lccccc}
\hline & \multicolumn{5}{c}{ Fertilizer rate $\left(\mathrm{t} \mathrm{ha}^{-1}\right.$ compost) } \\
\cline { 2 - 6 } & 10 & 20 & 30 & 40 & 50 \\
\hline N applied (mg N pot $\left.{ }^{-1}\right)$ & 464 & 928 & 1392 & 1856 & 2320 \\
NFU\% CRC & 14.7 & 9.5 & 11.2 & 10.4 & 10.8 \\
NFU\% AN & 70.3 & 79.0 & 76.3 & 76.7 & 67.0 \\
CRC: AN ratio (\%) & 20.9 & 12.0 & 14.7 & 13.6 & 16.2 \\
NPF\% CRC & 31.0 & 36.7 & 50.7 & 56.1 & 62.2 \\
NPF\% AN & 68.2 & 82.9 & 87.5 & 90.4 & 91.1 \\
CRC: AN ratio (\%) & 45.5 & 44.3 & 57.9 & 62.1 & 68.3 \\
ABN\% CRC & 19.9 & 20.5 & 20.5 & 16.3 & 15.8 \\
ABN\% AN & 71.6 & 88.4 & 91.6 & 93.0 & 82.7 \\
CRC: AN ratio (\%) & 27.7 & 23.2 & 22.4 & 17.5 & 19.1 \\
\hline
\end{tabular}


ments. The mean $\mathrm{N}$-fertilizer use from the compost source was $11.3 \%$ (range $9.5-14.7 \%$ ), and $73.0 \%$ from the $\mathrm{NH}_{4} \mathrm{NO}_{3}$ source (range $67.0-79.0 \%$ ). Plant $\mathrm{N}$ derived from fertilizer increased gradually with increasing compost rates (from 31.0 to $62.2 \%$ ) and $\mathrm{NH}_{4} \mathrm{NO}_{3}$ rates (from 68.2 to $91.1 \%$ ), due to the increase in soil available $\mathrm{N}$, but the compost: $\mathrm{NH}_{4} \mathrm{NO}_{3}$ ratio increased from 45.5 to $68.3 \%$. In contrast, there was a decrease in apparent bioavailable $\mathrm{N}$ in the compost, from $20.5\left(30 \mathrm{t} \mathrm{ha}^{-1}\right)$ to $15.8 \%\left(50 \mathrm{t} \mathrm{ha}^{-1}\right)$. A decrease in the compost: $\mathrm{NH}_{4} \mathrm{NO}_{3}$ ratio was also observed. This implies that the extent of compost- $\mathrm{N}$ mineralization was dependent on the rate of compost application, a result consistent with incubation studies of sewage sludge, where an inverse relationship between the percentage of organic $\mathrm{N}$ mineralized and the rate of application is commonly observed (Garau et al. 1986; Fine et al. 1989). This finding has been attributed (1) to a high $\mathrm{C}: \mathrm{N}$ ratio, inducing net $\mathrm{N}$ immobilization (Barbarika et al. 1985). (2) to induced soil salinity, inhibiting microbial activity (Tester and Parr 1983), and (3) to $\mathrm{NH}_{3}$ volatilization (Ryan and Keeny 1975). In pot bioassays, gaseous $\mathrm{N}$ losses are not determined, as occurs in many incubation studies. The results are related to "apparent" mineralization (inorganic $\mathrm{N}$ accumulation) rather than to total ammonification of organic N. Fine et al. (1989) reported high $N$ volatilization when high rates of sludge mixtures with sandy soils were used in incubation studies. The $\mathrm{NH}_{3}$ volatilized was correlated positively with the sludge content but negatively with cation-exchange capacity. In finer textured soils, superfluous $\mathrm{N}$ was susceptible to volatilization which was related to $\mathrm{NH}_{4}^{+}$adsorption. The soil used in the present study had a $40 \%$ clay content and a high cation-exchange capacity $\left(21.2 \mathrm{cmol} \mathrm{kg}{ }^{-1}\right)$. Moreover, increasing rates of compost application increased the soil cation-exchange capacity from $2 \%$ at $10 \mathrm{t} \mathrm{ha}^{-1}$ to $17 \%$ at $50 \mathrm{t} \mathrm{ha}^{-1}$ compared with the control. This implied a higher level of $\mathrm{NH}_{4}^{+}$adsorption and thus, under the present experimental conditions, significant losses of $\mathrm{NH}_{3}$ cannot be expected to explain the decrease in apparent bioavailable N (ABN\%). Compost-induced salinization is a better explanation of this finding. Electrical conductivity values in the soil solution after 6 months were 1.2, 2.2, 3.1, 3.8 and $4.1 \mathrm{dS}$ $\mathrm{m}^{-1}$ with increasing rates of compost application. Possibly, $3 \mathrm{dS} \mathrm{m}^{-1}$ is the limit value, beyond which a significant decrease in soil biological activity is produced.

Figure 3 shows the variations in relative efficiency over time. After 30 days, the compost was $43 \%$ as effective as $\mathrm{NH}_{4} \mathrm{NO}_{3}$ in supplying available $\mathrm{N}$ to the soil-plant system $\left(\mathrm{N}_{\mathrm{f}}+\mathrm{Ni}_{\mathrm{f}}\right), 41 \%$ considering ryegrass $\mathrm{N}$ removal $\left(\mathrm{N}_{\mathrm{f}}\right)$. Compost $\mathrm{N}$ efficiency gradually decreased with time. After 180 days, the relative efficiency for cumulative $\mathrm{N}_{\mathrm{f}}$ was $16 \%$ and $17 \%$ for cumulative $\mathrm{N}_{\mathrm{f}}+\mathrm{Ni}_{\mathrm{f}}$. For noncumulative $\mathrm{N}_{\mathrm{f}}$ data the negative trend was even more pronounced, from $41 \%$ in the 1 st month to only $6 \%$ in the 6th month. In comparison to the relative efficiency of non-cumulative $\mathrm{N}_{\mathrm{f}}+\mathrm{Ni}_{\mathrm{f}}$, an important difference was observed from day 60 , reflecting the lower rate of plant uptake of net mineralized $\mathrm{N}$.

The decrease in compost relative efficiency values was apparently in contradiction with the general idea that

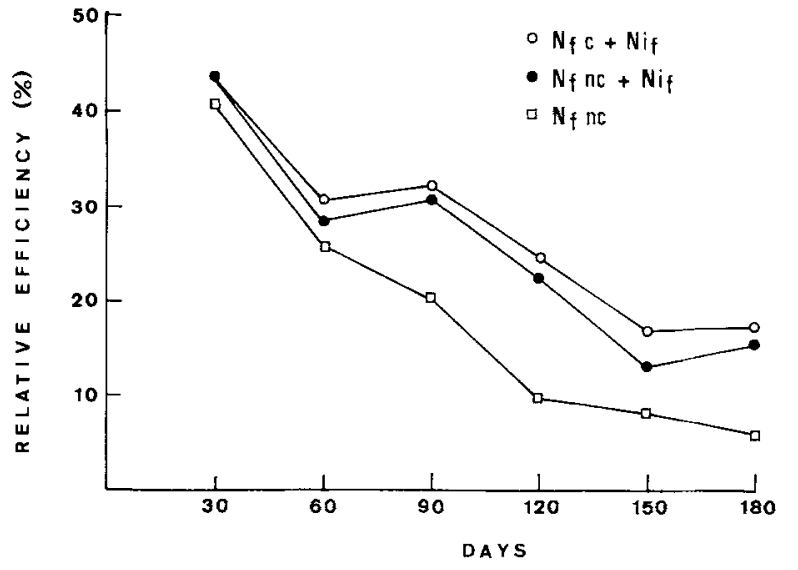

Fig. 3. Changes in relative efficiency over time of composted municipal refuse as a source of $\mathrm{N}$ compared to $\mathrm{NH}_{4} \mathrm{NO}_{3} . N_{f}$, fertilizer $\mathrm{N}$ taken up by ryegrass tops; $\mathrm{Ni}_{f}$, soil inorganic $\mathrm{N}\left(\mathrm{NH}_{4}^{+}+\mathrm{NO}_{3}^{-}\right)$derived from fertilizer; $c$, cumulative $\mathrm{N}$ values; $n c$; non-cumulative $\mathrm{N}$ values

composted organic materials have a greater residual effect on the $\mathrm{N}$ supply than inorganic $\mathrm{N}$ fertilizers, i.e., that the relative efficiency increases with time (Gallardo-Lara and Nogales 1987). This may be explained in terms of maturity (degree of "humification") of the compost. Positive net $\mathrm{N}$ mineralization in soils amended with immature compost is observed to a greater extent after a certain period and therefore the relative efficiency increases with time. The time necessary to reach maximum RE value depends on the degree of maturity attained during the composting process. Negative net $\mathrm{N}$ mineralization (net $\mathrm{N}$ immobilization) may even occur in composts with a $\mathrm{C}: \mathrm{N}$ ratio of $>25$ (Sims 1990). Our research implies that very mature composts $(\mathrm{C}: \mathrm{N}$ ratio $<12)$ release large amounts of mineral $\mathrm{N}$ after incorporation into soil, that the maximum RE value is quickly reached and subsequently RE decreases with time. This suggests that only the very labile organic $\mathrm{N}$ was mineralized during the first weeks of our experiment. As the more labile organic $\mathrm{N}$ disappears, and the most recalcitrant organic $\mathrm{N}$ predominates in the organic $\mathrm{N}$ pool, the mineralization rate can be expected to slow. This $\mathrm{N}$ pool includes, above all, "humified" organic matter which releases $\mathrm{N}$ slowly, and dead microbial tissue from compost, which is more resistant to decomposition (Mathur et al. 1990).

\section{Conclusions}

The results of this research imply that highly mature municipal refuse compost should not be considered a material that releases $\mathrm{N}$ poorly; after 30 days, this compost was $43 \%$ as effective as $\mathrm{NH}_{4} \mathrm{NO}_{3}$ in supplying inorganic $\mathrm{N}$ to the soil-plant system, and after 6 months, the percentage of apparent bioavailable $\mathrm{N}$ ranged from 16 to $21 \%$ of the total compost $\mathrm{N}$. This suggests that large inputs of inorganic $\mathrm{N}$ can be provided to the soil with high rates of this kind of compost, with a potential for $\mathrm{NO}_{3}^{-}-\mathrm{N}$ contamination. The use of highly matured composted municipal refuse may therefore be limited to agronomic application rates $\left(<50 \mathrm{tha}^{-1}\right)$. However, the moderate rates of compost applied in the present bioassay provided low levels of 
$\mathrm{N}$ over the experimental period as a whole, i.e., only a small fraction of the net mineralized compost $\mathrm{N}$ was taken up by the plants over this time. This result was ascribed to a partial biological immobilization. It should be pointed out that this apparent immobilization occurred with a highly matured compost $(C: N$ ratio $<12)$, but a net increase in yield and plant $\mathrm{N}$ uptake, in proportion to the rate of compost application, was observed throughout the assay. This pattern of $\mathrm{N}$ availability in highly matured municipal refuse compost, positive net mineralization but partial biological immobilization, is similar to the pattern of $\mathrm{N}$ availability in biologically active soils in which there is a continuous immobilization of inorganic $\mathrm{N}$ into organic phases and a mineralization of organic $\mathrm{N}$ into inorganic forms. Generally, a high input of $\mathrm{N}$ fertilizer into soil leads not only to a rapid increase in crop yields, but also to alterations in the equilibria of soil microbial populations, and groundwater contamination may occur. Thus, only the use of agronomic rates of highly matured compost, with a suitable and controlled supplement of $\mathrm{N}$ fertilizer, may be recommended as an agronomic management strategy. Moreover, the improvement in soil physical and nutritional qualities after compost amendment may result in a more efficient use of fertilizers, basically due to stimulation of the root system.

Acknowledgments. We thank the CSIC and CajaCanarias for financial support for this work. We also thank Pauline Agnew, from the staff of our Institute, for translating the original manuscript into English.

\section{References}

Barbarika A, Sikora LJ, Colacicco D (1985) Factors affecting the mineralization of nitrogen in sewage sludge applied to soils. Soil Sci Soc Am J 49:1403-1406

Benton Jones J, Wolf B, Mills HA (1991) Plant analysis handbook. Micro-Macro Publishing Inc., Athens, Ga

Bolton J, Nowakowski TZ, Lazarus W (1976) Sulphur-nitrogen interaction effects on the yield and composition of the protein nitrogen, non-protein nitrogen and soluble carbohydrates in perennial ryegrass. J Sci Food Agric 27:553-560

Bremner JM (1965a) Total nitrogen. In: Black CA, Evans DD, White JL, Ensminger LE, Clark FE, Dinauer RC (eds) Methods of soil analysis, Part 2. Agronomy 9, Am Soc Agron, Madison, Wis, pp $1149-1178$

Bremner JM (1965 b) Inorganic forms of nitrogen. In: Black CA, Evans DD, White JL, Ensminger LE, Clark FE, Dinauer RC (eds) Methods of soil analysis, Part 2. Agronomy 9, Am Soc Agron, Madison, Wis, pp $1179-1237$

Chanyasak V, Kubota $H$ (1981) Carbon/organic nitrogen ratio in water extract as measure of composting degradation. J Ferment Technol $59: 215-219$

De Bertoldi M, Zucconi F (1980) Microbiologia della transformazione dei rifiuti solidi urbani in compost e loro utilizzazione in agricoltura. Ing Ambientale 9:209-216

Fine P, Mingelgrin U, Feigin A (1989) Incubation studies of the fate of organic nitrogen in soils amended with activated sludge. Soil Sci Soc Am J 53:444-450

Gallardo-Lara F, Nogales R (1987) Effect of the application of town refuse compost on the soil-plant system: A review. Biol Wastes $19: 35-62$

Garau MA, Felipó MT, Ruiz de Villa MC (1986) Nitrogen mineralization of sewage sludge in soils. J Environ Qual 15:225 - 229
Giusquiani PL, Marucchini C, Businelli M (1988) Chemical properties of soils amended with compost of urban waste. Plant and Soil 109:73-78

Goh KM, Kee KK (1978) Effects of nitrogen and sulphur fertilization on the digestibility and chemical composition of perennial ryegrass (Lolium perenne L.). Pland and Soil 50:161-177

Greenwood DJ, Verstraeten LMJ, Draycott A (1987) Response of winter wheat to N-fertiliser: Quantitative relations for components of growth. Fertil Res 12:119-137

Harada Y, Inoko A (1980) The measurement of the cation-exchange capacity of compost for the estimation of the degree of maturity. Soil Sci Plant Nutr 26:127-134

Iglesias-Jiménez E, Pérez-García V (1989) Evaluation of city refuse compost maturity. A review. Biol Wastes 27:115-142

Iglesias-Jiménez E, Pérez-García V (1991) Composting of domestic refuse and sewage sludge. I. Evolution of temperature, $\mathrm{pH}, \mathrm{C} / \mathrm{N}$ ratio and cation-exchange capacity. Resour Conserv Recycl 6:45-60

Iglesias-Jiménez E, Pérez-García V (1992a) Composting of domestic refuse and sewage sludge. II. Evolution of carbon and some "humification" indexes. Resour Conserv Recycl 6:243-257

Iglesias-Jiménez E, Pérez-García V (1992b) Determination of maturity indices for city refuse composts. Agric Ecosyst Environ 38:331-343

Iglesias-Jiménez E, Pérez-García V, Espino M, Hernández-Moreno JM (1993) City refuse compost as a phosphorus source to overcome the P-fixation capacity of sesquioxiderich soils. Plant and Soil 148:115-127

Jarvis SC (1987) The effects of low, regulated supplies of nitrate and ammonium nitrogen on the growth and composition of perennial ryegrass. Plant and Soil 100:99-112

King LD (1984) Availability of nitrogen in municipal, industrial and animal wastes. J Environ Qual 13:609-612

Little TM, Hills FJ (1975) Statistical methods in agricultural research. University of California, Davis, Calif

Marchesini A, Allievi L, Comotti E, Ferrari A (1988) Long-term effects of quality-compost treatment on soil. Plant and Soil 106:253-261

Mathur SP, Schnitzer M, Schuppli P (1990) The distribution of nitrogen in peat-based composts of manure slurries and fisheries wastes. Biol Agric Hortic 7:153-163

Miyashita K, Kato T, Tsuru S (1982) Actinomycetes occurring in soil applied with compost. Soil Sci Plant Nutr 28:303-313

Nishio M, Kurano S (1980) Fluctuation patterns of microbial numbers in soil applied with compost. Soil Sci Plant Nutr 26:581-593

Pagliai M, Guidi G, La Marca M, Giachetti M, Lucamonte G (1981) Effects of sewage sludge and composts on soil porosity and aggregation. J Environ Qual 10:556-561

Perucci P (1990) Effect of the addition of municipal solid waste compost on microbial biomass and enzyme activities in soil. Biol Fertil Soils 10:221-226

Petruzzelli G (1989) Recycling wastes in agriculture: Heavy metal bioavailability. Agric Ecosyst Environ 27:493-503

Phae CG, Sasaki M, Shoda M, Kubota H (1990) Characteristics of Bacillus subtilis isolated from composts suppressing phytopathogenic microorganisms. Soil Sci Plant Nutr 36:575-586

Piccolo A, Mbagwu JSC (1990) Effects of different organic waste amendments on soil microaggregates stability and molecular sizes of humic substances. Plant and Soil 123:27-37

Rodriguez-Kabana R, Morgan-Jones G, Chet I (1987) Biological control of nematodes: Soil amendments and microbial antagonists. Plant and Soil 100:237-247

Ryan JA, Keeny DR (1975) Ammonia volatilization from surface-applied wastewater sludge. J Water Pollut Control Fed 47:386-393

Sims JT (1990) Nitrogen mineralization and elemental availability in soils amended with cocomposted sewage sludge. J Environ Qual 19:669-675

Tester CF, Parr JF (1983) Decomposition of sewage sludge compost in soil. 4. Effect of indigenous salinity. J Environ Qual 12:123-126

Van Assche C, Uyttebroeck P (1981) The influence of domestic waste compost on plant diseases. Acta Hortic 126:169-178 